\title{
ISOLATION OF FLAVONOIDS FROM Anaphalis busua AND THEIR ANTIBACTERIAL ACTIVITY
}

\author{
M. Rajbhandari ${ }^{1^{*}}$, U. Lindequist ${ }^{2}$ \\ ${ }^{I}$ Research Centre for Applied Science and Technology, Tribhuvan University, Kathmandu, Nepal, \\ ${ }^{2}$ Institute of Pharmacy, Department of Pharmaceutical Biology, University of Greifswald, D-17487, Germany \\ "Corresponding author: karmacharyameena@ gmail.com
}

(Received: February 27, 2020; Revised: April 27, 2020; Re-revised: May 6, 2020; Accepted: May 14, 2020)

\begin{abstract}
Anaphalis busua (Buch-Ham ex D. Don) is traditionally used to treat cuts and wounds. In the agar dilution method, the hexane extract of the aerial part of $A$. busua exhibited potent antibacterial activity with a minimal inhibitory concentration of $25 \mu \mathrm{g} / \mathrm{ml}$ against Bacillus subtilis and $500 \mu \mathrm{g} / \mathrm{ml}$ against Staphylococcus aureus. For the isolation of antibacterial compounds, the hexane extract was fractionated by silica gel and Sephadex LH 20 column chromatography. The direct bioautography method was used to determine the antibacterial activity of the fractions. The active fractions were finally purified by semi-preparative HPLC on $\mathrm{C}_{18}$ Phenomenex column under gradient condition. Four flavones derivatives of 3,5-dihydroxy-6,7,8-trimethoxyflavone (1), 3,5,7-trihydroxy-6-methoxyflavone (alnusin) (2), 3,5,7trihydroxy-8-methoxyflavone (3) and pinocembrin (4) were isolated, and their structures were established by ${ }^{1} \mathrm{H},{ }^{13} \mathrm{C}$, DEPT-135, and ESI-MS spectroscopy. These compounds were isolated for the first time from A. busua. The fatty acid profile of the hexane extract was analyzed by gas chromatography-mass spectrometry (GC-MS) by silylation with $\mathrm{N}$ methyl-N-trimethylsilyl-trifluoro-acetamide. Pinocembrin showed antibacterial activity with the minimum inhibitory concentration of $60 \mu \mathrm{g} / \mathrm{mL}$ against Bacillus subtilis and $420 \mu \mathrm{g} / \mathrm{mL}$ against Staphylococcus aureus.
\end{abstract}

Keywords: Anaphalis busua, antibacterial, fatty acids, flavone derivatives, GC-MS

\section{INTRODUCTION}

The genus Anaphalis belongs to the Asteraceae family, which consists of 110 different species distributed mostly in central and south Asia (Nesom, 2006). Anaphalis busua (Buch-Ham ex D. Don) is distributed throughout Nepal at the elevation range of 1500 to $2900 \mathrm{~m}$ in open areas. It is an annual herb propagated by seeds. In Nepalese traditional medicine, the juice of the plant is applied to cuts and wounds. The flowers and leaves are used against cough, cold and sore throat (Manandhar, 2002). The plant is not well investigated phytochemically and pharmacologically. In our previous investigation, the extracts of A. busua did not show antiviral and wound healing activities (Rajbhandari et al., 2009; ZimmermannKlemd et al., 2019). Phytochemical investigation of the aerial parts of $A$. araneosa indicated the presence of araneol and araneosol (Ali et al., 1979), helipyrone (Ali et al., 1982), sterols and phthaloids (Jakupovic et al., 1987). From the flowers, 5-methyl-n-hexatriacontane, anaphalisone, acyclic triterpenes, dulcioic acid and aerneosol (Sharma \& Ali, 1998) have been isolated. Similarly, from the roots, three new compounds, anaphalisoleanenoic acid, anaphalisoic acid, and araneosoic acid (Sharma et al., 2003) have been identified.

The alcoholic extract of leaf of A. busua indicated the presence of tiliroside, a flavonoidal glycoside, sitigmasterol, and $\beta$-sitosterol (Raturi et al., 2012). Antimicrobial drug resistance and hospital-acquired nosocomial infection are ever-growing problems (Struelens, 1998), and the search for more safe and effective antimicrobial agents is in high priority. Since the development of new antibiotics is a long process (Boucher et al., 2009), plant extracts and biologically active compounds isolated from plant species used in traditional medicine could be an alternative source of new drugs (Cowan, 1999; Giri \& Rajbhandari, 2018; Joshi \& Bashyal, 2018; Sharma et al., 2015). The present work reported the chemical constituents and antibacterial activity of hexane extract of $A$. busua.

\section{MATERIALS AND METHODS}

\section{General experimental procedure}

The thin layer chromatography (TLC) was carried out on pre-coated silica gel $\mathrm{GF}_{254}(0.2 \mathrm{~mm}$, Merck) using the solvent system hexane-ethylacetate $3: 2(\mathrm{v} / \mathrm{v})$, and it was visualized under a UV lamp (HP-UVIS, SARSREDTGRUPPE, DESAGA GmbH, Germany). The analytical gas chromatography was carried out on Agilent G1530N coupled with G2588A mass-spectrometer. The high performance liquid chromatographic (HPLC) purification was carried out on Shimadzu system controller SCL-10a with DAD using a semi-preparative Phenomenex $\mathrm{C}_{6}$ Phenyl 110 column $(250 \times 10 \mathrm{~mm}) .{ }^{1} \mathrm{HNMR}$ spectra were recorded on the Bruker Avance 300 DPX using TMS as an internal standard. Each sample $(2 \mathrm{mg}$ ) was dissolved in $0.5 \mathrm{ml} \mathrm{CDCl} l_{3}$ or Aceton- $d_{6}$ and transferred to a $5 \mathrm{~mm}$ BBO sample tube. ESI-MS was recorded on Finnigan TSQ 700 equipped with the Finnigan electrospray 
(Finnigan MTH GmbH, Bremen, Germany). The sample was dissolved in acetone and sprayed into the ionization chamber of the mass spectrometer.

\section{Plant material and extract}

The aerial part of A. busua was collected from Kalopani area of Johmsom district in November 2009 and authenticated by comparison with the herbarium species deposited at Central Department of Botany, Tribhuvan University, Kathmandu, Nepal. A voucher specimen (\#AB 463) was deposited at Research Centre for Applied Science and Technology, Tribhuvan University. The leaves and stem of dried and powdered plant materials (50 g) were successively extracted with hexane and methanol in a Soxhlet extractor. The solvent was evaporated under reduced pressure and finally dried by lyophilization to get the hexane $(1.13 \mathrm{~g})$ and methanol $(5.79 \mathrm{~g})$ extracts.

\section{Antimicrobial assay}

The antibacterial assay was performed using the agar diffusion method (Rajbhandari et al., 2007). Two Grampositive bacteria: Bacillus subtilis (ATCC 6051) and Staphylococcus aureus (ATCC 6538) were used. The minimum inhibitory concentration (MIC) was determined by the agar dilution method following the guidelines of the European Committee on Antimicrobial Susceptibility Testing (EUCAST, 2003). Muller Hinton agar was prepared according to the manufacturer's description and autoclaved at $121{ }^{\circ} \mathrm{C}$ for $15 \mathrm{~min}$. The stock solution of standard antibiotics was prepared by dissolving $1 \mathrm{mg}$ ampicillin in $1 \mathrm{~mL}$ DMSO and diluted to the total volume of $100 \mathrm{~mL}$ with Muller Hinton agar. The working solution was prepared by the two-fold serial dilution of the stock solution. The range of concentrations of ampicillin was from $0.1-6.4 \mu \mathrm{g} / \mathrm{mL}$. Similarly, the working solutions of extracts/pure compounds were prepared by serial dilution of the stock solutions prepared in different concentrations. About $20 \mathrm{~mL}$ of agar in each beaker cooled to $45-50^{\circ} \mathrm{C}$, added $1 \mathrm{~mL}$ of different concentrations of standard antibiotic/extracts/pure compounds prepared two-fold dilutions. After mixing properly, the content of each beaker was poured into the Petri plates. The plates were left to solidify at room temperature so that no drops of moisture remain on the surface of the agar. About $1 \mu \mathrm{L}$ of standard inoculums of test organisms $\left(10^{4} \mathrm{CFU}\right)$ was spotted in the agar plates with the help of micropipette, including a control plate without an antimicrobial agent. The inoculated spots were allowed to dry at room temperature and incubated in an inverted position at $37^{\circ} \mathrm{C}$ for $24 \mathrm{hrs}$. The lowest concentration of the agent that completely inhibits visible growth as judged by the naked eye, disregarding a single colony or a thin haze within the area of the inoculated spot corresponds to the MIC.

In bioassay-guided fractionation of antimicrobial compounds, the direct bioautography method was applied.
The developed TLC plate was sprayed with a microbial suspension. Then, the bioautogram was incubated at $25^{\circ} \mathrm{C}$ for $48 \mathrm{~h}$ under humid condition. For visualization of the microbial growth, $p$-iodonitrotetrazolium violet was sprayed onto the bioautogram, which was re-incubated at $37^{\circ} \mathrm{C}$ for 3-4 h (Begue \& Kline, 1972).

\section{GC-MS analysis of hexane extract}

Hexane extract $(1 \mathrm{mg})$ was mixed with methoxyamine hydrochloride in pyridine and treated with N-methyl-Ntrimethylsilyl-trifluoro-acetamide by heating in a microwave ( 3 minutes, 240 watts). $2 \mu \mathrm{L}$ of the solution was injected to the heated injector port $\left(230^{\circ} \mathrm{C}\right)$ of the gas chromatograph fitted with a capillary column (30 m DB$5 \mathrm{MS}$ with $0.25 \mathrm{~mm}$ internal diameter and $0.25 \mu \mathrm{m}$ film thickness). Helium was used as a carrier gas with a flow rate of $1 \mathrm{~mL} / \mathrm{min}$. The column temperature was initially maintained at $70{ }^{\circ} \mathrm{C}$ for $1 \mathrm{~min}$. It was gradually increased to $76{ }^{\circ} \mathrm{C}$ at a rate of $1.5^{\circ} \mathrm{C} / \mathrm{min}$ and finally increased to $330{ }^{\circ} \mathrm{C}$ at $5{ }^{\circ} \mathrm{C} / \mathrm{min}$. The injection split ratio was $1 / 25$. MS was operated in the electron impact mode with ionization energy of $70 \mathrm{eV}$, and the mass fragments were detected between $35 \mathrm{~m} / \mathrm{z}$ to $573 \mathrm{~m} / \mathrm{z}$. The mass transfer temperature was $250{ }^{\circ} \mathrm{C}$. The detected compounds in the gas chromatogram were identified by processing the GCMS data and comparing it with the mass spectral database of the National Institute of Standard and Technology, NIST.

\section{Bioassay Directed Fractionation and Purification}

The hexane extract $(1 \mathrm{~g})$ was subjected to silica gel column chromatography $(25 \mathrm{~cm} \times 2.5 \mathrm{~cm}$ ID, flow rate 1.5 $\mathrm{mL} / \mathrm{min})$ using a mixture of hexane-ethyl acetate $(3: 2$ $\mathrm{v} / \mathrm{v})$. The sub-fractions were collected, each consisted of 4 $\mathrm{mL}$, and they were monitored by thin-layer chromatography in solvent system hexane-ethyl acetate (3:2). Finally, the column was eluted with methanol. The sub-fractions were pooled into 15 main fractions $\left(\mathrm{F}_{1}-\mathrm{F}_{15}\right)$.

The antimicrobial activities of the fractions were monitored by the bio-autographic method. Eleven out of fifteen fractions showed antimicrobial activity. One of the most active fraction $\mathrm{F}_{8}(400 \mathrm{mg})$ was further subjected to Sephadex LH20 column chromatography $(31 \mathrm{~cm} \times 2 \mathrm{~cm}$ ID, the flow rate of $1.9 \mathrm{~mL} / \mathrm{min}$ ) and eluted with methanol. The sub-fractions were collected and pooled into five major fractions after the TLC examination $\left(\mathrm{F}_{8-1^{-}}\right.$ $\left.\mathrm{F}_{8-5}\right)$. The active fractions $\mathrm{F}_{6}(40 \mathrm{mg}), \mathrm{F}_{8-2}(95 \mathrm{mg}), \mathrm{F}_{8-3}$ $(80 \mathrm{mg})$ and $\mathrm{F}_{9}(50 \mathrm{mg})$ were purified by semi-preparative HPLC on $\mathrm{C}_{18}$ Phenomenex column employing a gradient elution using $0.1 \%$ phosphoric acid in water (A) and methanol (B). The gradient elution consisted of $80 \%$ A to $100 \% \mathrm{~B}$ for $30 \mathrm{~min}$ with a flow rate of $1.5 \mathrm{ml} / \mathrm{min}$. HPLC purification of fraction $\mathrm{F}_{9}$ gave compound (1), $\mathrm{F}_{8-2}$ gave compound (2), $F_{8-3}$ gave compound (3), and $F_{6}$ gave compound (4). The phosphoric acid residue was 
neutralized with ammonia and purified by passing through the $\mathrm{C}_{18}$ Phenomenex SPE cartridge.

\section{RESULTS AND DISCUSSION}

The hexane extract showed the potent antimicrobial activity against $B$. subtilis (inhibition zone $7 \mathrm{~mm}, 2 \mathrm{mg}$ extract/disc) and $S$. aureus (inhibition zones $6 \mathrm{~mm}, 2 \mathrm{mg}$ extract/disc) than the methanol extract (inhibition zone 1 $\mathrm{mm}$ against both $B$. subtilis and $S$. aureus, $2 \mathrm{mg}$ extract/disc) in our screening experiment using the disc diffusion method. Therefore, GC-MS analysis of the hexane extract was performed which allowed the identification of some fatty acids based on retention time (Rt) and fragmentation pattern in the mass spectrum and comparing with the standard NIST mass spectral database. They are myristic acid (Rt $29.48 \mathrm{~min}$ ), palmitic acid (Rt $29.72 \mathrm{~min}$ ), linolic acid (Rt $29.98 \mathrm{~min}$ ), oleic acid (Rt $30.52 \mathrm{~min}$ ), steric acid (Rt $32.95 \mathrm{~min}$ ), arachnic acid (Rt $35.95 \mathrm{~min}$ ), and lignoceric acid (Rt $36.46 \mathrm{~min}$ ). A portion of gas chromatogram with retention time between 20-40 minutes is shown in Fig 1.

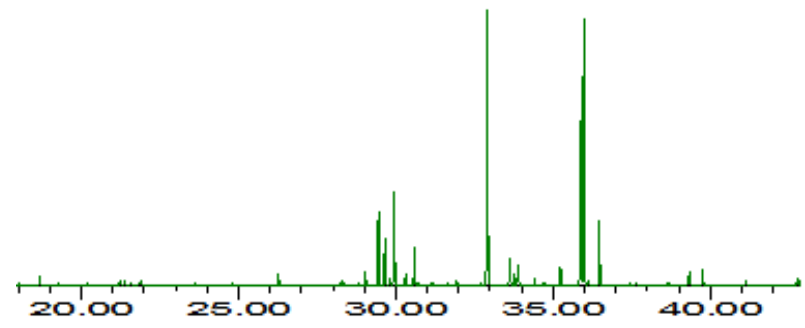

\section{Fig. 1. Gas chromatogram of hexane extract of $A$. busua}

Bio-assay directed fraction of the hexane extract led to the isolation of four flavone derivatives. The structures of these compounds were analyzed by UV, NMR, and mass spectroscopic methods. Compound (1) $\left(t_{R} 21.65\right.$ min, 18 $\mathrm{mg}$ ) was obtained as a yellowish-red crystalline solid. The UV spectrum showed absorption peaks at 272, 323, and $377 \mathrm{~nm}$. The ESI-MS showed $[\mathrm{M}+\mathrm{H}]^{+}$peak at $\mathrm{m} / \mathrm{z} 345$ $[\mathrm{M}-\mathrm{H}]^{-}$peak at $\mathrm{m} / \mathrm{z} 343$ that correspond to molecular formula $\mathrm{C}_{18} \mathrm{H}_{16} \mathrm{O}_{7}$. This indicated that it is a flavone or flavonol with two hydroxy and three methoxy groups. The ${ }^{13} \mathrm{C}$ NMR spectrum showed fifteen carbon signals. The DEPT-135 spectrum showed three methoxy groups (61.21 ppm, $61.75 \mathrm{ppm}$, and $62.11 \mathrm{ppm}$ ) and five methine groups (127.67 ppm doublet, 128.73 ppm doublet, and 130.50 ppm). The ${ }^{13} \mathrm{C}$ NMR spectrum confirmed an unsubstituted B-ring and a trimethoxy substituted A-ring.

The ${ }^{1} \mathrm{H}$ NMR profile was also consistent with that of a flavone structure. The doublet signal $8.25 \mathrm{ppm}$ was assigned for aromatic protons $\mathrm{H}^{\prime}$ and H6', a complex multiplate signals at $7.55 \mathrm{ppm}$ were due to the aromatic protons $\mathrm{H} 3$ ', and $\mathrm{H}^{\prime}$ ' and a signal at 7.25 is due to $\mathrm{H} 4$ '. A broad singlet at $6.75 \mathrm{ppm}$ was due to $\mathrm{OH}$ proton at $\mathrm{C}-3$. The three signals at 3.97, 4.00, and $4.13 \mathrm{ppm}$, represent the three methoxy protons. Comparison of these spectral data with literature indicated that compound (1) is 3, 5dihydroxy-6,7,8-trimethoxyflavone which has been isolated from Helichrysum graveolens, Helichrysum decumbens (Hansel \& Khaliefi, 1981; Tomas-Lorente, 1989).

Compound (2) ( $\left.t_{R} 20.34 \mathrm{~min}, 15 \mathrm{mg}\right)$ was obtained as a yellow crystalline solid. The UV spectrum showed absorption peaks at 268, 326, and $356 \mathrm{~nm}$. The ESI-MS showed $[\mathrm{M}+\mathrm{H}]^{+}$peak at $\mathrm{m} / \mathrm{z} 301$ and $[\mathrm{M}-\mathrm{H}]^{-}$peak at $\mathrm{m} / \mathrm{z}$ 299 indicated that it is a monomethoxy derivative of (1) The NMR signal also showed a signal for one methoxy proton at $4.05 \mathrm{ppm}$. A comparison of the NMR data with the literature suggested that the structure of compound (2) is 3,5,7-trihydroxy-6-methoxyflavone (alnusin) or 3,5,7trihydroxy-8-methoxyflavone. The presence of a strong fragment peak at $\mathrm{m} / \mathrm{z} 286$ in positive and 284 in negative ion mode due to the loss of methyl group [M-15] indicated the presence of the OMe group at the C- 6 position. By comparison of these spectral data with literature (Asakawa, 1971), compound (2) was identified as alnusin.

Compound (3) ( $\left.t_{R} 19.92 \mathrm{~min}, 15 \mathrm{mg}\right)$ was obtained as a yellow crystalline solid. The ESI-MS showed $[\mathrm{M}+\mathrm{H}]^{+}$ peak at $\mathrm{m} / \mathrm{z} 301$ and $[\mathrm{M}-\mathrm{H}]^{-}$peak at $\mathrm{m} / \mathrm{z} 299$ indicated that it is an isomer of compound (2) and identified as 3,5,7trihydroxy-8-methoxyflavone by comparison of NMR data with the literature (Proksch et al., 1982, Karasartov et al., 1992). Compound (4) ( $\left.\mathrm{t}_{\mathrm{R}} 19.22 \mathrm{~min}, 25 \mathrm{mg}\right)$ showed $[\mathrm{M}+\mathrm{H}]^{+}$peak at $\mathrm{m} / \mathrm{z} 257$ and $[\mathrm{M}-\mathrm{H}]^{-}$peak at $\mathrm{m} / \mathrm{z} 255$ in ESI-MS. The NMR showed signals at 2.85 (dd. H3a), 3.05 (dd, H3b), 6.01 (d, H6), 5.40 (dd, H2), 6.25 (d, H8), 7.30 (s, H3'/4'/5') and 7.45 (s, H2'/6') ppm. These NMR chemical shifts are identical to the chemical shift of pinocembrine (Bick et al., 1972, Jung et al., 1990). So compound (4) was identified as pinocembrin. The structures of the compounds are shown in Fig 2.

3,5-dihydroxy-6,7,8-trimethoxyflavone isolated from Helichrysum chasmolycicum showed moderate antifungal activity against Candida albicans (Suzgec-Selcuk \& Birteksoz, 2011). The antimicrobial property might be associated with the lack of hydroxyl groups in ring B, as in the case of galangin (Alfolayan \& Meyer, 1997). In protease inhibition activity, 3,5,7-trihydroxy-8methoxyflavone isolated from Helichrysum mechowianum showed weak inhibition of protease (Malolo et al., 2015). The cytotoxic activity of 3,5,7-trihydroxy-6methoxyflavone and pinocembrin isolated from the leaf of Chromolaena leivensis was determined on the prostate, breast, colon, cervix, and lung cancer cells using MTT assay.

The cytotoxicity of the 3,5,7-trihydroxy-6- methoxy flavone was found to be lower than the positive control, vincristine sulfate and pinocembrin also inhibited the cell 
proliferation (Torrenegra et al., 2016, Mendez-Callejas et al., 2018). Pinocembrine showed antibacterial and antioxidant (Drewes \& Vuuren, 2008), antifungal (Lago et al., 2004), antiviral (Lee et al., 2019), anti-inflammatory (Soromou et al., 2012) anticancer activities (Kumar et al., 2007, Punvittayagul et al., 2012). It has neuroprotective and anti-ischemic properties, so it is used as a promising drug candidate for the prevention and therapy of Alzheimer's disease and stroke (Liu et al., 2008, Shi et al., 2011). The presence of compounds (1-4) in A. busua demonstrate its traditional use in the treatment of various ailments.<smiles></smiles>

1-3

$$
\begin{aligned}
1 . \mathrm{R}_{1} & =\mathrm{R}_{2}=\mathrm{OH} ; \\
\mathrm{R}_{3} & =\mathrm{R}_{4}=\mathrm{R}_{5}=\mathrm{OMe} \\
\text { 2. } \mathrm{R}_{1} & =\mathrm{R}_{2}=\mathrm{R}_{4}=\mathrm{OH} ; \\
\mathrm{R}_{3} & =\mathrm{OMe}, \mathrm{R}_{5}=\mathrm{H} \\
3 . \mathrm{R}_{1} & =\mathrm{R}_{2}=\mathrm{R}_{4}=\mathrm{OH} ; \\
\mathrm{R}_{5} & =\mathrm{OMe} ; \mathrm{R}_{3}=\mathrm{H}
\end{aligned}
$$

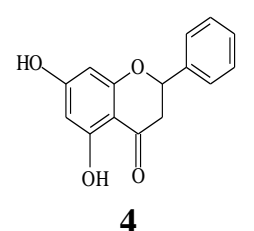

Fig. 2. Structure of the isolated compounds

\section{Antimicrobial assay}

The Agar dilution method was used to determine the MIC of the crude extracts and pinocembrin. The minimal inhibitory concentrations of extracts, pinocembrin, and ampicillin are given in Table 1.

Table 1. MIC $(\mu \mathrm{g} / \mathrm{ml})$ of extracts and pinocembrin

\begin{tabular}{lllll}
\hline Bacteria & Hexane & Methanol & Pinocembrin & Ampicillin \\
\hline B. subtilis & 25.0 & 200.0 & 60.0 & 0.8 \\
S. aureus & 500.0 & 200.0 & 420.0 & 0.4 \\
\hline
\end{tabular}

In the present investigation, the pure isolate showed only weak activity for the comparison to the extract. In such a case, the constituents in the extract collectively enhance the activity; however, on further purification, leading to the isolation of single compound(s), the relative potency of the compound of interest seems to diminish. Thus, it can assume that the combination of all the phytochemicals, including the fatty acids present in the extract, could have a stronger antimicrobial effect than the single compound alone.

\section{CONCLUSION}

Bioassay-guided fractionation of hexane extract of $A$. busua led to the isolation of 3,5-dihydroxy-6,7,8trimethoxyflavone, 3,5,7-trihydroxy-6-methoxyflavone (alnusin), 3,5,7-trihydroxy-8-methoxyflavone, and pinocembrin. Literature review revealed that these compounds were not isolated before from A. busua. Pinocembrin showed antibacterial activity against Grampositive bacteria B. subtilis and S. aureus. A. busua, which is used in ethno-medicine, could be the potential source of bioactive compounds.

\section{ACKNOWLEDGMENTS}

Authors would like to thank Dr. Stefan Kehraus, Institute for Pharmaceutical Biology, University of Bonn for recording NMR and mass spectrum and Dr. Martina Wurster, Institute of Biochemistry, University of Greifswald for antimicrobial assay.

\section{REFERENCES}

Alfolayan, A. J., \& Meyer, J. J. M. (1997). Antimicrobial activity of 3,5,7-trihydroxyflavon isolated from the shoot of Helichrysum aureonitens. Journal of Ethnopharmacology, 57, 177-181.

Ali, E., Bagchi, D. \& Pakrashi, S. C. (1982). New flavonoids from Anaphalis araneosa. Phytochemistry, 21, 243-244

Ali, E., Bagchi, D., \& Pakrashi, S. C. (1979). New flavonoids from Anaphalis araneosa. Phytochemistry, 18, 356-357.

Asakawa, Y. (1971). Chemical constituents of Alnus sieboldiana (BETULACEAE) II. The isolation and structure of flavonoids and stilbenes. Bulletin of the Chemical Society of Japan, 44, 2761-2766.

Begue, W. J., \& Klein, R. M. (1972). The use of tetrazolium salts in bioautographic procedure. Journal of Chromatography, 88, 182-184.

Bick, I. R. C., Brown, R. B., \& Hillis, W. E. (1972). Three flavanones from leaves of Eucalypt us sieberi. Australian Journal of Chemistry, 25, 449451.

Boucher, H. W., Talbot, G. H., \& Bradley, J. S. (2009). Bad bugs, no drugs: no ESKAPE! An update from the infectious diseases society of America. Clinical Infectious Disease, 48, 1-12.

Cowan, M. M. (1999). Plant products as antimicrobial agents. Clinical Microbiology Reviews, 12, 564582.

Drewes, S. E., \& van Vuuren, S. F. (2008). Antimicrobial acylphloroglucinols and dibenzyloxy flavonoids from flowers of Helichrysum gymnocomum . Phytochemistry, 69, 1745-1749.

EUCAST. (2003). Determination of minimum inhibitory concentrations (MICs) of antibacterial agents by broth dilution. Clinical Microbiology and Infection, 9, ix-xv. https://doi.org/10.1046/j.14690691.2003.00790.x.

Giri, D. P., \& Rajbhandari, M. (2018). Phytochemical analysis and constituents of hexane extract of 
Melastoma malabathricum L. Journal of Institute of Science and Technology 23, 18-25.

Hansel, R., \& Khaliefi, F. (1981). 3.5-Dihydroxy-6.7.8trimethoxyflavon aus Helichrysum graveolens: Bestätigung der Konstitution. Zeitschrift fur Naturforschung, 36, 1171-1172.

Jakupovic, J., Schuster, A., Sun, H., Bohlamann, F. \& Bhakuni, D. S. (1987). Prenylated phthalides from Anaphalis araneosa and Helichrysum platypterum. Phytochemistry, 26, 580-581.

Joshi, S., \& Bashyal, S. (2018). Study on the chemical constituents and antibacterial activity of essential oil of Acorus calamus L. rhizomes of Rupendehi district (Nepal). Journal of Institute of Science and Technology, 23, 57-60.

Jung, J. H., Pummangura, S., Chaichantipyutha, C., Patrapanich, C., \& McLaughlin, J. L.(1990). Bioactive constituents of Melodorum fruticosum. Phytochemistry, 29, 1667-1670.

Karasartov, B. S, Kurkin, V. A., \& Zapesochnaya, G. G. (1992). Coumarins and flavonoids of the flowers of Helichrysum italicum. Chemistry of Natural Compounds, 28, 504-505.

Kumar, M. A. S., Nair, M., Hema, P. S., Mohan, J., \& Santhoshkumar, T. R. (2007). Pinocembrin triggers bax-dependent mitochondrial apoptosis in colon cancer cells. Molecular Carcinogenesis, 46, 231241.

Lago, J. H. G., Ito, A. T., Fernandes, C. M., Young, M. C. M., \& Kato, M. J. (2012). Secondary metabolites isolated from Piper chimonantifolium and their antifungal activity. Natural Product Research, 26, 770-773.

Lee, J. L., Loe, M. W. C., Lee, R. C. H., \& Chu, J. J. H. (2019). Antiviral activity of pinocembrin against Zika virus replication. Antiviral Research, 167, 1324.

Liu, R., Gao, M., Yang, Z. H., \& Du, G. H. (2008). Pinocembrin protects rat brain against oxidation and apoptosis induced by ischemia-reperfusion both in vivo and in vitro. Brain Research, 1216, 104-115.

Malolo, F. A. E, Nouga, A. B., \& Wessjohann, L. (2015). Protease-inhibiting, molecular modeling and antimicrobial activities of extracts and constituents from Helichrysum foetidum and Helichrysum mechowianum (compositae). Chemistry Central Journal, 9, 32.

Manandhar, N. P. (2002). Plants and People of Nepal. Timber Press, Portland, Oregon.
Mendez-Callejas, G. M, Rodriguez, J., \& TorrenegraGuerrero, R. D. (2018). Anticancer potential of (R) 5,7-dihydroxyflavanone from leaves of Chromolaena Leivensis (Hieron) on cancer cells. International Journal of Current Pharmaceutical Review and Research, 9, 48-54.

Nesom, G. L. (2006). Flora of North America. Oxford University Press, p. 426.

Proksch, M., Proksch, P., Weissenboeck, G., \& Rodriguez E. (1982). Flavonoids from leaf resin of Adenostoma sparsifolium. Phytochemistry, 21, 1835-1836.

Punvittayagul, C., Pompimon, W., Wanibuchi, H., Fukushima, S., \& Wongpoomchai, R. (2012). Effects of pinocembrin on the initiation and promotion stages of rat hepatocarcinogenesis. Asian Pacific Journal of Cancer Prevention, 13, $2257-$ 2261.

Rajbhandari, M., Mentel, R., Jha, P. K., Chaudhary, R. P, Bhattarai, S., Gewali, M. B., Karmacharya, N., Hipper, M., \& Lindequist, U. (2009). Antiviral activity of some plants used in Nepalese traditional medicine. Evidence Based Complimentary and Alternative medicine, 6, 517-522.

Rajbhandari, M., Schoepke, Th., Mentel, R., \& Lindequist, U. (2007). Antibacterial and antiviral naphthazarins from Maharanga bicolor. Die Pharmazie, 62, 633-635.

Raturi, R., Sati, S. C, Singh, H., Sati, M. D., \& Badoni, P. P. (2012). Phytochemical examination of Anaphalis busua leaves pp 105-106. In: Chemistry of Phytopotentials: Health Energy and Environmental Perspectives. Berlin/ Heidelberg, German: Springer.

Sharma, K. R., Kalauni, S. K., \& Awale, S. (2015). Antioxidant, phytotoxic and antimicrobial activities of methanolic extract of Bauhinia variegata barks. Journal of Institute of Science and Technology, 20, $37-41$.

Sharma, S. K. \& Ali, M. (1998). Isolation of some novel phytoconstituents from Anaphalis araneosa flowers. Journal of Aromatic and Medicinal Plant Science, 20, 352-358.

Sharma, S. K., Ali, M., \& Mir, S. R. (2003). Isolation of some novel phytoconstituents from Anaphalis araneosa roots. Indian Journal of Chemistry, 42, 2858-2862.

Shi, L. L., Chen, B. N., \& Gao, M. (2011). The characteristics of therapeutic effect of pinocembrin in transient global brain ischemia/reperfusion rats. Life Sciences, 88, 521-528. 
Soromou, L. W., Chu, X., \& Jiang, L. (2012). In vitro and in vivo protection provided by pinocembrin against lipopolysaccharide- induced inflammatory responses. International Immunopharmacology, 14, 66-74

Struelens, M. J. (1998). The epidemiology of antimicrobial resistance in hospital-acquired infections: problems and possible solutions. British Medical Journal, 317, 652-654

Suzgec-Selcuk, S., \& Birteksoz, A. S. (2011). Flavonoids of Helichrysum chasmolycicum and its antioxidant and antimicrobial activities. South African Journal of Botany, 77, 170-174.

Tomas-Lorente, F., Iniesta-Sanmartin, E., TomasBarberan, F. A., Trowitzsch-Kienast, W., \& Wray, V. (1989). Antifungal phloroglucinol derivatives and lipophilic flavonoids from Helichrysum decumbens. Phytochemistry, 28, 1613-1615.

Torrenegra, R. D., Rodriguez, J., Rodriguez, O. E. Palau V. E., \& Mendez, G. M. (2016). Antiproliferative activity of 3,5,7- trihydroxy-6-methoxy flavone obtained from Chromolaena leivensis (Hieron) on cancer cell lines of Breast, Prostate, Lung, Colon, and Cervix. Pharmacology, 1, 7-11.

Zimmermann-Klemd, A. M, Konradi, V., Steinborn, C., Uecker, A., Falanga, C. M., Woelfle, U., Huber, R., Juergenliemk, G., Rajbhandari, M., \& Gruendemann, C. (2019). Influence of traditionally used Nepalese plants on wound healing and immunological properties using primary human cells in vitro. Journal of Ethnopharmacology, 235, 415 423. 